\title{
On Decoloniality
}


On Decoloniality interconnects a diverse array of perspectives from the lived experiences of coloniality and decolonial thought/praxis in different local histories from across the globe.

The series identifies and examines decolonial engagements in Eastern Europe, the Caribbean, the Americas, South Asia, South Africa, and beyond from standpoints of feminisms, erotic sovereignty, Fanonian thought, post-

Soviet analyses, global indigeneity, and ongoing efforts to delink, relink, and rebuild a radically distinct praxis of living. Aimed at a broad audience, from scholars, students, and artists to journalists, activists, and socially engaged intellectuals, On Decoloniality invites a wide range of participants to join one of the fastest-growing debates in the humanities and social sciences that attends to the lived concerns of dignity, life, and the survival of the planet.

A SERIES EDITED BY Walter Mignolo \& Catherine Walsh 


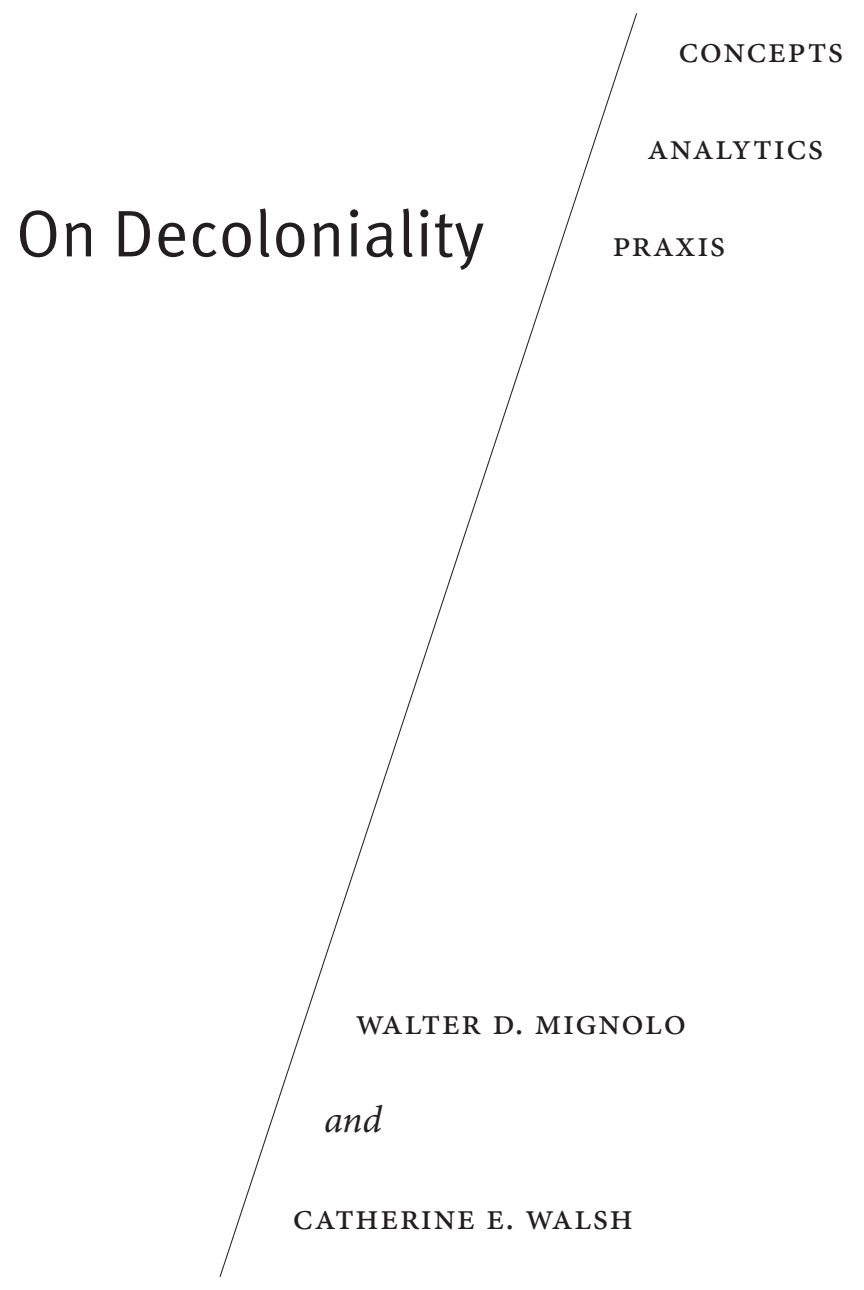

DUKE UNIVERSITY PRESS Durham and London 2018 
(C) 2018 Duke University Press

All rights reserved

Printed in the United States of America on acid-free

paper $\infty$

Designed by Matt Tauch

Typeset in Minion Pro by Westchester Publishing Services

Library of Congress Cataloging-in-Publication Data

Names: Mignolo, Walter, author. | Walsh, Catherine E., author.

Title: On decoloniality : concepts, analytics, praxis /

Walter D. Mignolo and Catherine E. Walsh.

Description: Durham : Duke University Press, 2018. | Series: On

decoloniality | Includes bibliographical references and index.

Identifiers: LCCN 2017053249 (print) | LCCN 2017056840

(ebook)

ISBN 9780822371779 (ebook)

ISBN 9780822370949 (hardcover : alk. paper)

ISBN 9780822371090 (pbk. : alk. paper)

Subjects: LCSH: Postcolonialism-Philosophy. |

Decolonization-Philosophy. | Imperialism-Philosophy. |

Power (Social sciences)—Philosophy. | Civilization,

Modern-Philosophy.

Classification: LCC JV51 (ebook) | LCC JV51 .M544 2018 (print) |

DDC 325/.301-dc23

LC record available at https://lccn.loc.gov/2017053249

Cover art: Adolfo Albán Achinte, Marejada, de la serie

"Andanias" 
TO ANÍBAL QUIJANO / who gave us, and the world, the concept of coloniality. In memory of Fernando Coronil. And in celebration of the 2016 "Standup" resurgence at Standing Rock. 
This page intentionally left blank 